\title{
The Effect of Prior Financial Performance on Organizational Reputation and Earnings Management
}

\author{
Quang Linh HUYNH ${ }^{1}$, Nguyen Van NGUYEN ${ }^{2}$
}

Received: May 06, 2019 Revised: September 16, 2019 Accepted: September 24, 2019

\begin{abstract}
The paper aims to investigate the linkage among prior financial performance, organizational reputation and earnings quality. Firstly, it examines the influence of prior financial performance on organizational reputation and on earnings quality. Secondly, this research explores the moderating role that prior financial performance plays in the causal relationship from organizational reputation to earnings quality. Thirdly, the mediating role of organizational reputation in the effect of prior financial performance on earnings quality is analyzed. The empirical findings show that, prior financial performance positively affects both earnings quality and organizational reputation that in turn partly mediates the causal connection from prior financial performance to earnings quality; whereas prior financial performance imposes a positive moderation in the influence of organizational reputation on earnings quality. This research is expected to provide scholars and practitioners with a thorough understanding of the complex link among prior financial performance, organizational reputation and earnings quality. That helps them to deliver good decisions on the investment of suitable resources in maintaining and enhancing their organizational reputation, which assures a higher quality of reported earnings that in turn improves involved stakeholders' confidence in their firm. This likely leads the firms to gain better performance in the future.
\end{abstract}

Keywords : Corporate Finance, Financial Performance, Organizational Reputation, Earnings Management, Vietnam

JEL Classification Code : C51, G28, G32, M41, L25

\section{Introduction}

Financial performance is extremely important to stock exchanges, which help investors to assess firms' financial health more exactly (Du \& Shen 2018). Earnings reports are using accounting information that is related to the measurement of financial performance, the ability of which indicates the real income condition and forecasts upcoming cash flows and fluctuations in the market prices of stocks more accurately (Pagalung \& Sudibdyo, 2018). However,

1 First Author, Vice Dean, School of Economics and Law, Tra Vinh University, Vietnam. Email: huynhquanglinh@tvu.edu.vn

2 Corresponding Author, Director, Resource Development Institute, Tra Vinh University, Vietnam. [Postal Address: 126 Nguyen Thien Thanh Street, Ward 5, Tra Vinh City, Tra Vinh Province, 940000, Vietnam] Email: nguyenvannguyenrdi@tvu.edu.vn

(c) Copyright: Korean Distribution Science Association (KODISA)

This is an Open Access article distributed under the terms of the Creative Commons Attribution Non-Commercial License (http://Creativecommons.org/licenses/by-nc/4.0/) which permits unrestricted noncommercial use, distribution, and reproduction in any medium, provided the original work is properly cited. discretionary accruals of accounting earnings can be employed as the means for executives to manage real earnings (Shawn, Leese, Jung, \& Moon, 2016). There are many reasons for firms to manage their real earnings (Bergstresser \& Philippon, 2006). Firstly, the compensation for managers is attached to financial performance, which encourages unethical managers to manipulate earnings to satisfy targeted financial expectations. Secondly, flexible accounting principles offer chances for opportunistic managers to mange earnings easily. Thirdly, it is so difficult for investors as well as other stakeholders to discover earnings management that is negatively and directly connected to earnings quality (Acker, Giacomino, \& Bellovary, 2007; Ewert \& Wagenhofer, 2012).

Furthermore, a firm's prior financial performance is confirmed as a salient driver of succeeding organizational reputation that can decide earnings management of the firm (Hammond \& Slocum, 1996; Lu, 2013). The relationships among prior financial performance, organizational reputation and earnings quality have been analyzed in many 
prior studies (Roberts \& Dowling, 2002; Luchs, Stuebs, \& Sun, 2009; Liu, Vredenburg, \& Steel, 2016; Ferry, Adebimpe, George, \& Lenu, 2017; Huynh, 2018; Du \& Shen, 2018; Pagalung \& Sudibdyo, 2018). Nonetheless, they have investigated the links in separate research models. Further, the moderation of prior financial performance and the mediation of organizational reputation are established in this research; however, to the best of my knowledge, none of the related prior studies have discussed and examined that moderation and that mediation in the relationships among these variables. Therefore, the objective of this research is to examine the influence of prior financial performance on organizational reputation and on earnings quality, explore the moderating role of prior financial performance, and then investigate the mediating role of organizational reputation. This research is the first to examine the moderating role of prior financial performance and the mediating role of organizational reputation in the links among prior financial performance, organizational reputation and earnings quality.

\section{Literature Review}

Ethical directors usually have a tendency to be proactive with socially responsible actions and consider them as very good manner; therefore, they possibly deliver more exact and dependable reported earnings (Pyo \& Lee, 2013). Stakeholders' prejudices anchored in earnings management has been taken into consideration for a long time (Wu, 2010). Earnings attributes are regarded very essential to users of financial statements (Salerno, 2014). The management of earnings is imperative ethical issue related to ethical behaviors of the executive directors in financial reporting (Armstrong, 1993). Much research on the management of earnings has usually viewed it as being directly connected to the quality of earnings (Ewert \& Wagenhofer, 2012), where a high extent of earnings management implies a low earnings quality.

Earnings quality of a company is suggested dependent on whether it is informative about the company's financial performance; numerous facets of which have not thoroughly been investigated (Dechow, Ge, \& Schrand, 2010); although this relationship has been directly or indirectly analyzed in many previous studies. For instance, this link may originate from adjustments of reported earnings in order to meet various sides relevant to the company that need taking into account when the motives of earnings management are evaluated (Dechow, Sloan, \& Sweeney, 1995). The practice of earnings management is fundamentally determined by reported positive financial performance, and so there is adequate evidence of earnings management to avoid reported financial losses (Burgstahler \& Dechev, 1997). A company's operating profit affects the extent of earnings management and instability in financial performance is one of the motives for executive directors to make use of earnings management practice to provide the preferred financial reports to the stakeholders.

In addition, Kinney and McDaniel (1989) asserted faults in income statements in which organizational income appears in the bottom are fewer in effective companies than in poorly profitable ones. High financial performance contributes importantly to earnings quality (Dechow et al., 2010). Negative financial performance generates motives for business executives to take on earnings management that will produce income statements with low quality. Financial specialists and other stakeholders are ardently interested in their concerned company's accounting reporting, which they can because rely on to evaluate prior financial performance that along with other variables such as financial leverage, investment decisions or organizational size, imposes a direct influence on the quality of earnings (Warrad, 2017).

Taking the same line of thinking, Du and Shen (2018) identified that, there is no need for a company to manage its real earnings to meet concerned stakeholder's expectations if it achieves superior financial performance. On the contrary, the standpoint grounded on slack resources theory suggested that prior high financial performance would provide sufficient resources to for firms to consider more socially responsible behaviors and so it is more concerned about ethically managerial behaviors such as earnings management (Surroca, Tribó, \& Waddock,2010). For the meantime, Parte-Esteban and García (2014) assessed the effect of organizational characteristics on the quality of earnings and emphasized the importance of prior financial loss of a company on manipulating behaviors of executive directors, which could undermine the quality of reported earnings. Meantime, Pagalung and Sudibdyo (2018) established several influential variables that determine the quality of earnings comprise previous financial performance and firm risks.

In relation to organizational reputation, it is regarded as an illustration of a company's previous actions, which depict the company's ability to create good results to various stakeholders. As such, organizational reputation builds up from a company's previous resource allocations and histories and forms moral hurdles, which restrain firms' own current actions (Fombrun, 1997). Besides, it has been acknowledged not only a consequence of previous financial performance (Roberts \& Dowling, 2002; Liu et al., 2016), but also a cause of earnings quality (Ferry et al., 2017; Luchs et al., 2009; Huynh, 2018).

For example, Hammond and Slocum (1996) discovered that financial performance is a salient determinant of subsequent organizational reputation, which can outline the company's decisions of earnings management (Lu, 2013).In the similar line of thinking, other prior studies recommended that financial performance will provide companies with ample resources to maintain and improve future organizational reputation, which enables the companies to behave more responsibly and ethically to the involved communities (Roberts \& Dowling, 2002; BlajerGołębiewska \& Kozłowski, 2017). This implies that the 
companies possibly deliver earnings reports with higher quality to avoid reputational damage (Cao, Myers, \& Omer, 2012).

Financial performance provides the company a financial resource to support social responsibility to the stakeholders, which enhances future firm image, which is an essential of organizational reputation (Surroca et al., 2010), as the stakeholders' reaction to the social responsibility can affect their perception of the company that help firm reputation to be steadily developed (Roberts \& Dowling, 2002). According to the perspective of Cao et al. (2012), the directors' concerns of firm reputation likely enable them to react suitably in managerial work, the importance of which is to supervise the earnings manipulating behaviors of business executives. Furthermore, the development of firm reputation probably affects managerial behavior as well as attitude in managing reported earnings, urging them to act more ethically so that their firms can attain sustainable performance instead of interim benefits (Fich \& Shivdasani, 2007; Blajer-Golebiewska, 2014). Moreover, the role of firm reputation in facilitating firms to produce earnings reports with high quality has also been underlined in a study of Ferry et al. (2017). It is one of the most important factors to stimulate suitable reactions in managerial work, which will result in earnings statements with better quality; because firms commonly follow their strategic goal of developing and improving firm reputation (Luchs et al., 2009).
As above discussed, previous financial performance are a cause of both organizational reputation and earnings quality. Therefore, when examining the reputation- earnings quality link, we should incorporate the moderator of previous financial performance that likely influences this link. In summary, it can suggest that: previous financial performance likely moderates the influence of organizational reputation on earnings quality. Additionally, previous financial performance possibly affects organizational reputation that then improves earnings quality, which is regarded a consequence of previous financial performance. In addition to that, based on the mediating conditions stipulated by Baron and Kenny (1986), it can suggest that: organizational reputation likely mediates the influence of previous financial performance on earnings quality. Overall, it could recommend the following hypotheses:

H1: Previous financial performance positively influences organizational reputation;

H2: Previous financial performance positively influences earnings quality;

H3: Previous financial performance moderates the link from organizational reputation to earnings quality;

H4: Organizational reputation mediates the link from previous financial performance to earnings quality. Overall, the proposed research model is illustrated Figure 1.

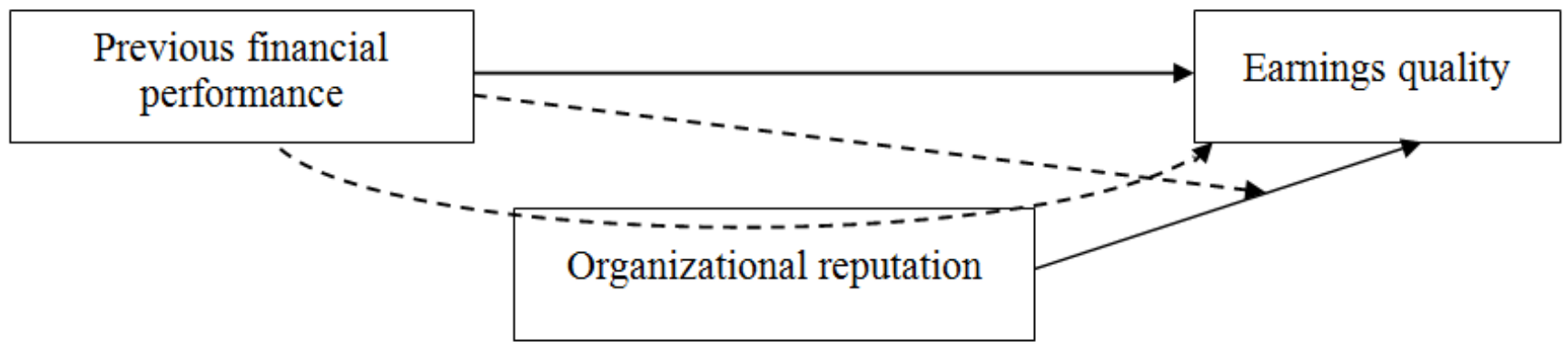

Figure 1: Proposed Research Model

\section{Methodology}

Previous financial performance (PFP) was grounded on Surroca et al. (2010) to use Tobin's q ratio by dividing the sum of the total equity market value and total liabilities book value by the sum of the total equity book value and total liabilities book value of the company, adapted from Latif, Bhatti, and Raheman (2017). Organizational reputation (ORR) is computed on the ranking levels evaluated by Forbes Vietnam in the 50 best firms list. The selected firms were ranked from the worst (ranking 50) to the best (ranking $1)$.

Earnings quality (EQU) was adapted from Francis, LaFond, Olsson, and Schipper (2004) and Gaio and Raposo
(2014) and was evaluated with seven dimensions. They are (1) Accruals quality (AQU) is Negative standard deviation

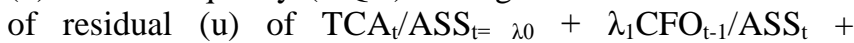
$\lambda_{2} \mathrm{CFO}_{\mathrm{t}} / \mathrm{ASS}_{\mathrm{t}}+\lambda_{3} \mathrm{CFO}_{\mathrm{t}+1} / \mathrm{ASS}_{\mathrm{t}}+\mathrm{u}$; (2) Persistence (PER) is $\alpha_{1}$ of $\mathrm{NIBE}_{\mathrm{t}} / \mathrm{ASS}_{\mathrm{t}}=\alpha_{0}+\alpha_{1} \mathrm{NIBE}_{\mathrm{t}-1} / \mathrm{ASS}_{\mathrm{t}}+\quad \xi ; \quad$; Predictability (PRE) is Negative square root of variance of residual $(\varepsilon)$ of $\mathrm{NIBE}_{\mathrm{t}} / \mathrm{ASS}_{\mathrm{t}}=\alpha_{0}+\alpha_{1} \mathrm{NIBE}_{\mathrm{t}-1} / \mathrm{ASS}_{\mathrm{t}}+\varepsilon$; (4) Smoothness (SMO) is Negative standard deviation ratioб $\left(\mathrm{NIBE}_{\mathrm{t}} / \mathrm{ASS}_{\mathrm{t}}\right) / \sigma\left(\mathrm{CFO}_{\mathrm{t}} / \mathrm{ASS}_{\mathrm{t}}\right)$; (5) Value relevance (VAR) is Explanatory power of $\mathrm{RET}_{\mathrm{t}}=\delta+\delta_{1} \mathrm{NIBE}_{\mathrm{t}} / \mathrm{MVA}_{\mathrm{t}}+$ $\lambda$; (6) Timeliness (TIM) is Explanatory power of $\mathrm{NIBE}_{\mathrm{t}} / \mathrm{MVA}_{\mathrm{t}}=\Theta_{0}+\Theta_{1} \mathrm{NEGt}+\Theta_{2} \mathrm{RET}_{\mathrm{t}}+\Theta_{3} \mathrm{NEG}_{\mathrm{t}} \cdot \mathrm{RET}_{\mathrm{t}}+\zeta$; (7) Conservatism $(\mathrm{CON})$ is $\left(\Theta_{2}+\Theta_{3}\right) / \Theta_{2}$ of NIBE $/ \mathrm{MVA}_{\mathrm{t}}=\Theta_{0}$ $+\Theta_{1}$ NEGt $+\Theta_{2}$ RET $_{t}+\Theta_{3}$ NEG $_{t} \cdot$ RET $_{t}+\zeta$. Where:TCA $t=$ 
Total current accruals in year $\mathrm{C}_{\mathrm{t}} \mathrm{CFO}_{\mathrm{t}}=$ Cash flow from operations in year $\mathrm{ASS}_{\mathrm{t}}=$ Total assets at the begining of year ${ }_{\mathrm{t}} \mathrm{NIBE}_{\mathrm{t}}=$ Income before extraordinary items in year ${ }_{\mathrm{t}}$; $\mathrm{MAV}_{\mathrm{t}}=$ Market value at the beginning of year $; \mathrm{RET}_{t}=12-$ month return ending three months after the end of year, $\mathrm{NEG}_{\mathrm{t}}=1$ if $\mathrm{RET}_{\mathrm{t}}<0$ and zero otherwise. In contrast with the earnings attributes measured by Francis et al. (2004) and Gaio and Raposo (2014) where larger values of attribute indicate lower earnings quality, the attributes of earnings quality in this research were evaluated in the reverse way where larger values of attribute correspond to higher earnings quality. The calculation of the EQU items employed rolling 6-year windows.

Controlling variables were included into the research model to control possible influences on endogenous variables. In this research, the controlling variables were selected, modified from prior research (Surroca et al., 2010; Cao et al., 2012; Roberts \& Dowling, 2002; Latif et al., 2017). Firm liquidity is a ratio of the total current assets to the total current liabilities (LIQ). Firm size is measured as the logarithm of the total asset book value (SIZ). Capital intensity is a ratio of the total asset book value to the total sales (CIN). Firm leverage is a ratio of the total debt to the total equity book value (LEV).

The research population encompassed the publicly listed firms that were voted by Forbes Vietnam in the list of the 50 best Vietnamese firms through the four-year period from 2012 to 2015; so there were totally 200 firm-year observations obtained from the population. Of these 200 firm-year observations, just there were 187 adequately informative firm-year observations that satisfy the sampling size as Hair, Black, Babin, Anderson, and Tatham (2010) suggested. The data was collected to test the research hypotheses. To test the causal hypotheses, multiple regression analyses were employed. To test the moderating hypothesis, the analytic techniques recommended by Baron and Kenny (1986) were applied. To test the mediating hypothesis, the procedures stipulated by Sobel (1982) were used.

\section{Empirical Results}

\subsection{Construct Reliability}

There is a latent variable analyzed in the research that is earnings quality inyear $\mathrm{t}_{\mathrm{t}}\left(\mathrm{EQU}_{\mathrm{t}}\right)$. Therefore, this construct was examined for internal consistence within the construct using the criteria suggested by Hair et al. (2010). The reliability analysis was carried out and the findings are presented in Table 1. The results indicate that, the item-total correlations take the values from 0.568 to 0.754 that satisfy the smallest threshold of 0.5 ; and also the Cronbach's alpha gain 0.879 , more than 0.7 , the smallest stipulated value. In addition, the values of Cronbachs' alphas, if any item is removed, vary from 0.874 to 0.894 , all of which exceed 0.896 as the current Cronbach's alpha. These figures imply a good internal consistence for the construct of earnings quality in year. ${ }_{\text {. }}$ Next, the extraction method using principal component analysis was applied to calculate the aggregate proxy of earnings quality in year ${ }_{t}\left(\mathrm{EQU}_{\mathrm{t}}\right)$.

\subsection{Test of Causal Relationship}

Table 1: Reliability analysis

\begin{tabular}{|c|c|c|c|}
\hline $\begin{array}{l}\text { Measured } \\
\text { items }\end{array}$ & $\begin{array}{c}\text { Item-total } \\
\text { Correlations }\end{array}$ & $\begin{array}{l}\text { Cronbach's } \alpha \text { if } \\
\text { Item Deleted }\end{array}$ & $\begin{array}{c}\text { Cronbach's } \\
\alpha\end{array}$ \\
\hline $\mathrm{AQU}_{\mathrm{t}}$ & 0.725 & 0.877 & \multirow{7}{*}{0.896} \\
\hline $\mathrm{PER}_{\mathrm{t}}$ & 0.568 & 0.894 & \\
\hline $\mathrm{PRE}_{t}$ & 0.754 & 0.874 & \\
\hline $\mathrm{SMO}_{\mathrm{t}}$ & 0.710 & 0.880 & \\
\hline VAR $_{\mathrm{t}}$ & 0.683 & 0.883 & \\
\hline TIM $_{\mathrm{t}}$ & 0.754 & 0.874 & \\
\hline $\mathrm{CON}_{\mathrm{t}}$ & 0.695 & 0.881 & \\
\hline
\end{tabular}

To test causal Hypotheses 1 and 2, multiple regressions were employed. The results of regression analyses are exhibited in Table 2. The effect of previous financial performance on organizational reputation is illustrated in Model $1\left(\beta=0.176 ; \mathrm{P}_{\mathrm{t}}<1 \% ; \mathrm{R}^{2}=84.2 \% ; \mathrm{F}=192.357 ; \mathrm{P}_{\mathrm{f}}<\right.$ $1 \%)$. Previous financial performance in company with controlling variables explains $84.2 \%$ of variation in organizational reputation with $\mathrm{F}$ of 192.357 at the $1 \%$ significance level. Furthermore, the findings also indicate that, previous financial performance positively influences organizational reputation with the estimator of 0.176 gaining the $1 \%$ significance level. These results statistically support Hypothesis 1 at the $1 \%$ statistical significance level. The impact of previous financial performance on earnings quality is demonstrated in Model $2\left(\beta=0.157 ; \mathrm{P}_{\mathrm{t}}<1 \% ; \mathrm{R}^{2}=\right.$ $\left.70.4 \% ; \mathrm{F}=86.017 ; \mathrm{P}_{\mathrm{f}}<1 \%\right)$. Previous financial performance together with controlling variables explains $70.4 \%$ of variant in earnings quality with $\mathrm{F}$ of 86.017 at the $1 \%$ statistical significance level. In addition, the results also show that, previous financial performance positively affects earnings quality with the estimator of 0.157 obtaining the $1 \%$ statistical significance level, providing a statistical support for Hypothesis 2 at the $1 \%$ statistical significance level.

\subsection{Test of Moderation}

To test Hypothesis 3, the hierarchical regression analysis (suggested by Baron and Kenny (1986)) that underwent two separate regressions was performed. The main effects of previous financial performance and organizational reputation on earnings quality were investigated by analyzing Model 3, where earnings quality functions as a dependent variable. Subsequently, the interaction element was included into Model 3 to analyze Model 4. To mitigate multicollinearity, standardized coefficients of previous financial performance and organizational reputation were 
multiplied to create an element regarded as a proxy for the interaction between previous financial performance and organizational reputation. The findings are exhibited in Table 3.

Table 2: Multiple regressions *** 1\%; ${ }^{* *} 5 \%$; ${ }^{*} 10 \%$ Significance

\begin{tabular}{|c|c|c|}
\hline \multirow{2}{*}{$\begin{array}{l}\text { Explanatory } \\
\text { variables }\end{array}$} & \multicolumn{2}{|c|}{ Explained variables } \\
\hline & ORR $_{t}($ Model 1) & $\mathrm{EQU}_{\mathrm{t}}($ Model 2) \\
\hline Constant & 0.141 & $-2.616^{\star \star \star}$ \\
\hline $\mathrm{PFP}_{\mathrm{t}-1}$ & $0.176^{* * *}$ & $0.157^{* * *}$ \\
\hline $\mathrm{LIQ}_{\mathrm{t}}$ & $0.105^{*}$ & $0.115^{*}$ \\
\hline$S I Z_{t}$ & $0.305^{*+*}$ & $0.128^{* *}$ \\
\hline $\mathrm{CIN}_{\mathrm{t}}$ & 0.065 & $0.125^{*}$ \\
\hline LEV $_{t}$ & $0.285^{* * *}$ & $0.210^{* * *}$ \\
\hline $\mathrm{R}^{2}$ & $84.2 \%$ & $70.4 \%$ \\
\hline $\mathrm{F}$ & 192.357 & 86.017 \\
\hline$P_{f}$ & 0.000 & 0.000 \\
\hline
\end{tabular}

As the figures in Table 3 show, previous financial performance and organizational reputation positively affect earnings quality at the $5 \%$ and $1 \%$ significance levels respectively with the influential estimator of 0.114 and 0.247 respectively in Model 3; and 0.136 and 0.250 respectively in Model 4.

Table 3: Moderating analyses

*** $1 \%$; ** $5 \%$; ${ }^{*} 10 \%$ Significance

\begin{tabular}{|c|c|c|}
\hline \multirow{2}{*}{$\begin{array}{l}\text { Independent } \\
\text { variables }\end{array}$} & \multicolumn{2}{|c|}{ Dependent variable } \\
\hline & $\mathrm{EQU}_{\mathrm{t}}($ Model 3) & $\mathrm{EQU}_{\mathrm{t}}($ Model 4) \\
\hline Constant & $-2.651^{* * *}$ & $-2.647^{* \star *}$ \\
\hline $\mathrm{LIQ}_{\mathrm{t}}$ & 0.089 & $0.113^{*}$ \\
\hline $\mathrm{SIZ}_{\mathrm{t}}$ & 0.053 & 0.016 \\
\hline $\mathrm{CIN}_{\mathrm{t}}$ & $0.109^{*}$ & $0.124^{* *}$ \\
\hline $\mathrm{LEV}_{\mathrm{t}}$ & $0.140^{*}$ & 0.115 \\
\hline $\mathrm{PFP}_{\mathrm{t}-1}$ & $0.114^{\star *}$ & $0.136^{* *}$ \\
\hline $\mathrm{ORR}_{\mathrm{t}}$ & $0.247^{* * *}$ & $0.250^{* * *}$ \\
\hline ORR $_{t^{\star}}$ PFP $_{t-1}$ & & $6.408^{* *}$ \\
\hline $\mathrm{R}^{2}$ & $71.7 \%$ & $72.5 \%$ \\
\hline $\mathrm{F}$ & 76.138 & 67.439 \\
\hline $\mathrm{P}_{\mathrm{F}}$ & 0.000 & 0.000 \\
\hline $\begin{array}{c}\text { Test of increases } \\
\text { in } R^{2} \text { : }\end{array}$ & \multicolumn{2}{|c|}{$\Delta R^{2}=0.8 \% ; P_{c}=0.026$} \\
\hline
\end{tabular}

The adding of the interrelation between previous financial performance and organizational reputation into Model 3 to establish Model 4 augments the explanatory power from $71.7 \%$ for Model 3 to $72.5 \%$ for Model 4 . A change of the explanatory power is $0.8 \%$ at the $5 \%$ significance level. Furthermore, the interrelation between previous financial performance and organizational reputation positively influences earnings quality with a 6.408 influential estimate at the statistical significance level of $5 \%$. These findings provide support for Hypothesis 3 at the 5\% statistical significance level. It implies that, previous financial performance influences the causal link from organizational reputation to earnings quality in the way that previous financial performance strengthens the causal linkage between organizational reputation and earnings quality.

\subsection{Test of Mediation}

Table 4: Summary of regressions for mediation *** $1 \%$; ${ }^{* *} 5 \%$; ${ }^{*} 10 \%$ Significance

\begin{tabular}{|c|c|c|c|}
\hline \multirow{2}{*}{$\begin{array}{l}\text { Independent } \\
\text { variables }\end{array}$} & \multicolumn{3}{|c|}{ Dependent variable } \\
\hline & $\begin{array}{c}\text { ORR }_{\mathrm{t}} \\
\text { (Model 1) }\end{array}$ & $\begin{array}{c}\mathrm{EQU}_{\mathrm{t}} \\
\text { (Model 2) }\end{array}$ & $\begin{array}{c}\text { EQU }_{\mathrm{t}} \\
\text { (Model 3) }\end{array}$ \\
\hline Constant & 0.141 & $-2.616^{* * *}$ & $-2.651^{* \star *}$ \\
\hline $\mathrm{LIQ}_{\mathrm{t}}$ & $0.105^{*}$ & $0.115^{*}$ & 0.089 \\
\hline$S I Z_{t}$ & $0.305^{* * *}$ & $0.128^{* *}$ & 0.053 \\
\hline $\mathrm{CIN}_{\mathrm{t}}$ & 0.065 & $0.125^{*}$ & $0.109^{*}$ \\
\hline LEV $_{t}$ & $0.285^{* * *}$ & $0.210^{* *+}$ & $0.140^{*}$ \\
\hline $\mathrm{PFP}_{\mathrm{t}-1}$ & $0.176^{* * *}$ & $0.157^{* * *}$ & $0.114^{* *}$ \\
\hline $\mathrm{ORR}_{\mathrm{t}}$ & & & $0.247^{* * *}$ \\
\hline $\mathrm{R}^{2}$ & $84.2 \%$ & $70.4 \%$ & $71.7 \%$ \\
\hline $\mathrm{F}$ & 192.357 & 86.017 & 76.138 \\
\hline$P_{F}$ & 0.000 & 0.000 & 0.000 \\
\hline
\end{tabular}

To test Hypothesis 4, the statistical significance of mediation was examined with the procedures as recommended by Baron and Kenny (1986). Three models based on Model 1, Model 2 and Model 3; which are summarized in Table 4, were used to analyze the mediating effect. As Table 4 indicates, Fisher statistical parameters of the three models range from 192.357 for Model 1 down to 76.138 for Model 3 with the significance levels all less than $1 \%$; demonstrating that the three models all fit good enough to the collected data. Model 1 suggests that, previous financial performance influences organizational reputation with the coefficient of 0.176 at the $1 \%$ significance level $(\beta$ $\left.=0.176 ; \mathrm{P}_{\mathrm{t}}<1 \%\right)$; whereas Model 2 indicates that, previous financial performance influences earnings quality with the parameter of 0.157 at the $1 \%$ significance level $(\beta=0.157$; $\mathrm{P}_{\mathrm{t}}<1 \%$ ). In addition, previous financial performance and organizational reputation together impact earnings quality (in Model 3) with the estimates of 0.114 and 0.247 respectively at the $5 \%$ and $1 \%$ significance levels respectively $\left(\beta_{1}=0.114 ; \mathrm{P}_{\mathrm{t} 1}<5 \% ; \beta_{2}=0.247 ; \mathrm{P}_{\mathrm{t} 2}<1 \%\right)$.

Table 5: Mediating analysis

Source: Author's own calculations

\begin{tabular}{|c|c|c|c|c|c|}
\hline Mediator & $\begin{array}{c}\text { Causal } \\
\text { variable }\end{array}$ & $\begin{array}{c}\text { Outcome } \\
\text { variable }\end{array}$ & $\mathbf{t}_{\text {indirect }}$ & S.E. & $\mathbf{P}_{\mathbf{t}}$ \\
\hline $\mathrm{ORR}_{\mathrm{t}}$ & $\mathrm{PFP}_{\mathrm{t}-1}$ & $\mathrm{EQU}_{\mathrm{t}}$ & 2.3127 & 0.0188 & 0.0207 \\
\hline
\end{tabular}

In the comparison of Model 2 and Model 3, when the interaction between previous financial performance and organizational reputation is included into the research model, the impact of previous financial performance on earnings quality declines from 0.157 in Model 2 down to 0.114 in Model 3. Moreover, the reliability levels of the impact also decreases from 99\% in Model 2 down to $95 \%$ in Model 3. All of them support Hypothesis 4. However, for the 
robustness, the analyses as Sobel (1982) stipulated were applied to test the statistical significance of the mediation. As the results in Table 5 illustrate, organizational reputation partly partially intervenes in the causal relationship between previous financial performance and earnings quality at the $1 \%$ statistical significance level $\left(\mathrm{t}_{\text {indirect }}=2.3127\right.$, S.E. $=0.0188$, $\left.\mathrm{P}_{\mathrm{t}}<5 \%\right)$. These mean that, organizational reputation transmits a part of the influence of previous financial performance on earnings quality indirectly through itself.

\section{Conclusion}

This study investigated the associations among prior financial performance, organizational reputation and earnings quality, taking into consideration the moderating role of prior financial performance and the mediating role of organizational reputation. Prior scholars have analyzed the effect of prior financial performance on organizational reputation and earnings quality as well as the influence of organizational reputation on earnings quality(Roberts \& Dowling, 2002; Luchs et al., 2009; Liu et al. 2016; Ferry et al., 2017; Huynh, 2018; Du \& Shen, 2018; Pagalung \& Sudibdyo, 2018). However, they investigated these effects in separate research models. Furthermore, none of them has examined the moderating role of prior financial performance as well as the mediating role of organizational reputation in these complicated links. This research provides a thorough explanation on the association among prior financial performance, organizational reputation and earnings quality by investigating the moderation of prior financial performance and the mediation of organizational reputation.

The empirical results discovered that prior financial performance plays a vital role in improving organizational reputation and earnings quality; and especially it plays a moderating role in the link between them. The relationship organizational reputation and earnings quality becomes more vigorous at higher levels of prior financial performance. This implies that firms with high prior financial performance and good organizational reputation likely behave more ethically in accounting practices, which produce higher qualified reports of earnings. The findings also underline the mediating role of organizational reputation in managing the effect of prior financial performance on earnings quality. The appearing of organizational reputation in the research model will mitigate the direct effect of prior financial performance on earnings quality and make it become negligible, because a part of the effect is transmitted to earnings quality via organizational reputation.

This study offers an insight into the complicated relationships among prior financial performance, organizational reputation and earnings quality to financial researchers as well as to executive directors who should pay more attention to organizational reputation by investing more financial resources in enhancing reputation that will control managerial behaviors more ethically, and so more qualified reports of earnings will be made. All of them will allow firms to win stakeholders' confidence, which help to gain more completive advantages and finally better upcoming financial performance will be achieved for the firms.

\section{References}

Acker, M., Giacomino, D., \& Bellovary, L. J. (2007). Earnings management and its implications: Educating the accounting profession. The CPA Journal, 77(8), 6468.

Armstrong, M. B. (1993). Ethics and professionalism in accounting education: A sample course. Journal of Accounting Education, 11(1), 77-92.

Baron, R. M., \& Kenny, D. A. (1986). The moderatormediator variable distinction in social psychological research: Conceptual, strategic, and statistical considerations. Journal of Personality and Social Psychology, 51(6). 1173-1182.

Bergstresser, D., \& Philippon, T. (2006). CEO incentives and earnings management. Journal of Financial Economics, 80(3), 511-529.

Blajer-Golebiewska, A. (2014). Corporate reputation and economic performance: The evidence from Poland. Economics \& Sociology, 7(3), 194-207.

Blajer-Gołębiewska, A., \& Kozłowski, A. (2017). Financial determinants of corporate reputation: A short-term approach. Managerial Economics, 17(2), 179-201.

Burgstahler, D., \& Dichev, I. D. (1997). Earnings management to avoid earnings decreases and losses. Journal of Accounting \& Economics, 24(1), 99-126.

Cao, Y., Myers, L. A., \& Omer, T. C. (2012). Does company reputation matter for financial reporting quality: Evidence from restatements. Contemporary Accounting Research, 29(3), 956-990.

Dechow, P. M., Ge, W., \& Schrand, C. (2010). Understanding earnings quality: A review of the proxies, their determinants and their consequences. Journal of Accounting and Economics, 50(2-3), 344-401.

Dechow, P. M., Sloan, R. G., \& Sweeney, A. P. (1995). Detecting earnings management. The Accounting Review, 70(2), 193-225.

Du, Q., \& Shen, R. (2018). Peer performance and earnings management. Journal of Banking and Finance, 89(C), 125-137.

Ewert, R., \& Wagenhofer, A. (2012). Earnings management, conservatism, and earnings quality. Foundations and Trends in Accounting, 6(2), 65-186.

Ferry, B. G., Adebimpe, O. U., George, T. P., \& Lenu, G. W. (2017). Corporate reputation and earnings quality of listed firms in Nigeria. Journal of Research in Business and Management, 5(4), 14-22.

Fich, E. M., \& Shivdasani, A. (2007). Financial fraud, 
director reputation, and shareholder wealth. Journal of Financial Economics, 86(2), 306-36.

Fombrun, C. J., \& Van Riel, C. B. M. (1997). The reputational landscape. Corporate Reputation Review, $1(1 / 2), 5-13$.

Francis, J., LaFond, R., Olsson, P. M., \& Schipper, K. (2004). Costs of equity and earnings attributes. The Accounting Review, 79(4), 967-1010.

Gaio, C., \& Raposo, C. C. (2014). Corporate governance and earnings quality: International evidence. Journal of Accounting and Finance, 14(3), 52-74.

Hair, J. F., Black, W. C., Babin, B. J., Anderson, R. E., \& Tatham, R. L. (2010). Multivariate Data Analysis (Ed.). Upper Saddle River, NJ: Pearson Prentice Hall.

Hammond, S. A., \& Slocum, J. W. (1996). The impact of prior firm financial performance on subsequent corporate reputation. Journal of Business Ethics, 15(2), 159-165.

Huynh, Q. L. (2018). Earnings quality with reputation and performance. Asian Economic and Financial Review, $8(2), 269-278$.

Kinney, W., \& McDaniel, L. (1989). Characteristics of firms correcting previously reported quarterly earnings. Journal of Accounting and Economics, 11, 71-93.

Latif, K., Bhatti, A. A., \& Raheman, A. (2017). Earnings quality: A missing link between corporate governance and firm value. Business \& Economic Review, 9(2), 255280.

Liu, X., Vredenburg, H., \& Steel, P. (2016). Determinants and moderators of corporate reputation: A meta-analysis. In Academy of Management Proceedings. Briarcliff Manor, NY: Academy of Management.

$\mathrm{Lu}, \mathrm{X}$. (2013). The impact of corporate reputation on earnings management decisions (Doctorial dissertation, Durham University).

Luchs, C., Stuebs, M., \& Sun, L. (2009). Corporate reputation and earnings quality. Journal of Applied
Business Research, 25(4), 47-54.

Pagalung, G., \& Sudibdyo, B. (2018). The determinant factors of earnings quality and economic consequences. EKUITAS Journal Ekonomidan Keuangan, 16(1), 105122.

Parte-Esteban, L., \& García, C. F. (2014). The influence of firm characteristics on earnings quality. International Journal of Hospitality Management, 42, 50-60.

Pyo, G., \& Lee, H. Y. (2013). The association between corporate social responsibility activities and earnings quality: Evidence from donations and voluntary issuance of CSR reports. Journal of Applied Business Research, 29(3), 945-962.

Roberts, P. W., \& Dowling, G. R. (2002). Corporate reputation and sustained superior financial performance. Strategic Management Journal, 23(12), 1077-1093.

Salerno, D. (2014). The role of earnings quality in financial analyst forecast accuracy. Journal of Applied Business Research, 30(1), 255-276.

Shawn, H., Leese, H., Jung, J., \& Moon, S. (2016). Relation between real earnings management and audit quality. Journal of Applied Business Research, 32(3), 967-980.

Sobel, M. E. (1982). Asymptotic confidence intervals for indirect effects in structural equation models. Sociological Methodology, 13, 290-312.

Surroca, J., Tribó, J. A., \& Waddock, S. (2010). Corporate responsibility and financial performance: Role of intangible resources. Strategic Management Journal, 31(5), 463-490.

Warrad, L. H. (2017). The influence of leverage and profitability on earnings quality: Jordanian case. International Journal of Academic Research in Business and Social Sciences, 7(10), 62-81.

$\mathrm{Wu}, \mathrm{W}$. W. (2010). Beyond business failure prediction. Expert Systems with Applications, 37(3), 2371-237. 